TITLE:

\title{
Electrochemical properties of lead fluoride electrode in fluoride shuttle battery
}

\section{$\operatorname{AUTHOR}(S):$}

Konishi, Hiroaki; Minato, Taketoshi; Abe, Takeshi; Ogumi, Zempachi

\section{CITATION:}

Konishi, Hiroaki ...[et al]. Electrochemical properties of lead fluo ride electrode in fluoride shuttle battery. Journal of Electroanalytical Chemistry 2018, 826: 60-64

\section{ISSUE DATE:}

2018-10-01

URL:

http://hdl.handle.net/2433/243332

\section{RIGHT:}

(c) 2018. This manuscript version is made available under the CC-BY-NC-ND 4.0 license

http://creativecommons.org/licenses/by-nc-nd/4.0/; The full-text file will be made open to the public on 1 October 2020 in accordance with publisher's 'Terms and Conditions for Self-Archiving'.; この論文は出版社版でありません。引用の際 には出版社版をご確認ご利用ください。; This is not the published version. Please cite only the published version. 


\section{Electrochemical properties of lead fluoride electrode in fluoride shuttle battery}

Hiroaki Konishi,, ${ }^{\mathrm{a}, \mathrm{z}}$ Taketoshi Minato, ${ }^{\mathrm{b}, \mathrm{z}}$ Takeshi Abe, ${ }^{\mathrm{c}, \mathrm{z}}$ and Zempachi Ogumi, ${ }^{\mathrm{a}}$

${ }^{a}$ Office of Society-Academia Collaboration for Innovation, Kyoto University, Gokasho, Uji, Kyoto 611-0011, Japan

${ }^{b}$ Office of Society-Academia Collaboration for Innovation, Kyoto University, Katsura, Nishikyo, Kyoto 615-8510, Japan

${ }^{\mathrm{c}}$ Graduate School of Global Environmental Studies, Kyoto University, Katsura, Nishikyo, Kyoto 6158510, Japan

\section{${ }^{\mathrm{z}}$ Corresponding author}

Hiroaki Konishi

E-mail: hiroaki.konishi.yj@hitachi.com

Taketoshi Minato

E-mail: minato.taketoshi.5x@kyoto-u.ac.jp

Takeshi Abe

E-mail: abe@elech.kuic.kyoto-u.ac.jp 
Journal of Electroanalytical Chemistry, 826, 60-64 (2018).

\section{Present address}

Hiroaki Konishi

Research \& Development Group, Hitachi Ltd.

Hitachi, Ibaraki 319-1292, Japan

E-mail: hiroaki.konishi.yj@hitachi.com

\section{Keywords}

Fluoride shuttle battery; Lead fluoride; Electrolyte; XRD; AAS 


\section{Abstract}

Recently, the reversible charge-discharge reaction of $\mathrm{BiF}_{3}$ electrode for fluoride shuttle battery (FSB) that can be used as a promising candidate for next-generation battery are observed using a liquid-based electrolyte. In this study, we investigate the electrochemical performance of $\mathrm{PbF}_{2}$ as an active material for the FSB. To increase the electronic conductivity, the $\mathrm{PbF}_{2}$ was mixed with carbon, and the composite material between $\mathrm{PbF}_{2}$ and carbon, $\mathrm{PbF}_{2} / \mathrm{C}$, is formed. High charge and discharge capacities are obtained for $\mathrm{PbF}_{2} / \mathrm{C}$ during the first cycle. Although the charge and discharge capacities gradually decreased, the charge-discharge reactions occurred in the second and third cycles. To confirm the progress of the charge-discharge reactions, the crystal structure change of the active material during charging and discharging in the first and second cycles is evaluated using X-ray diffraction (XRD). From the $\mathrm{XRD}$ results, the formation of $\mathrm{Pb}$ and $\mathrm{PbF}_{2}$ during discharging and charging can be confirmed, indicating that the discharge $\left(\mathrm{PbF}_{2}+2 \mathrm{e}^{-} \rightarrow \mathrm{Pb}+2 \mathrm{~F}^{-}\right)$and charge $(\mathrm{Pb}+$ $\left.2 \mathrm{~F}^{-} \rightarrow \mathrm{PbF}_{2}+2 \mathrm{e}^{-}\right)$reactions progress in both the first and second cycles. 


\section{Introduction}

Lithium-ion batteries (LIBs) are extensively used as secondary batteries for many electronic devices [1-3]. To increase the use of secondary batteries, many research institutions have investigated a variety of next-generation high-energy-density batteries such as sodium, magnesium, potassium, lithium/oxygen batteries [4-7]. Recently, batteries that utilize anion migration to perform the electrochemical reaction have been developed [8-15]. In 2011, Reddy et al. reported a new all-solid battery which utilize the migration of fluoride ions [8]. For this battery, the metal fluoride and metal were used as the active material, and fluoride ions migrated between metal fluoride and metal through a solid electrolyte. Since this study was conducted, the progress of electrochemical reaction of several metal fluorides using a solid electrolyte has been reported [8-11]. Furthermore, the battery using a liquid-based electrolyte has also been researched $[12,13]$. Our group has devoted attention to a battery that utilizes the fluoride-ion shuttling in a liquid-based electrolyte $[16,17]$. However, the supporting electrolyte salt such as cesium fluoride (CsF) hardly dissolved in the organic solvent [17]. To increase the solubility of CsF in the organic solvent, anion acceptor (AA) was added in the organic solvent [17]. Using the liquid-based electrolyte comprising organic solvent (bis[2-(2-methoxyethoxy)ethyl] ether (tetraglyme: G4)), supporting electrolyte salt (CsF), and AA (fluorobis(2,4,6-trimethylphenyl)borane (FBTMPhB)), the discharge and charge reactions of $\mathrm{BiF}_{3}$ successfully progressed, and the progress of both the reactions were confirmed using X-ray diffraction (XRD). Using the XRD results, the 
discharge reaction of $\mathrm{BiF}_{3}$ was observed to completely progress; however, the charge reaction progressed partially [17]. To obtain high capacities during both charging and discharging, high ionic and electronic conductivities are required for the active material. The $\mathrm{PbF}_{2}$-based compounds exhibit fluoride ion conductivity [18-21]; therefore, $\mathrm{PbF}_{2}$ was selected as an active material for the fluoride shuttle battery (FSB). It has been reported that the high adhesion state with carbon improved the charge and discharge capacities of metal fluorides for the active materials of LIBs due to the increased electronic conductivity [22-32]. This method can be used for the active material of the FSB. Thus, in the current study, the composite electrode of $\mathrm{PbF}_{2}$ and carbon, $\mathrm{PbF}_{2} / \mathrm{C}$, was formed using a ball mill (FRITSCH; PULVERISETTE 7). The electrochemical performance of $\mathrm{PbF}_{2} / \mathrm{C}$ was evaluated using the electrolyte comprising of G4, CsF, and FBTMPhB. Furthermore, to confirm the progress of the charge-discharge reactions, the crystal structure change of the active material was confirmed using XRD.

\section{Experimental}

2.1. Preparation of the electrolyte

The CsF (Tokyo Chemical Industry Co., Ltd), FBTMPhB (Tokyo Chemical Industry Co., Ltd), and G4 (KISHIDA CHEMICAL Co., Ltd) were used as the fluoride salt, the AA, and the organic solvent, respectively. The G4 containing $0.45 \mathrm{~mol} \mathrm{dm}^{-3} \mathrm{CsF}$ and $0.5 \mathrm{~mol} \mathrm{dm}^{-3} \mathrm{FBTMPhB}$ was used 
as the electrolyte. The electrolyte was prepared in a glove box under high purity argon.

2.2. Preparation of the active material

The $\mathrm{PbF}_{2}$ (Aldrich) was used as the active material. This was pulverized for $1 \mathrm{~h}$ in a planetary ball mill at $1100 \mathrm{rpm}$, and was then $80 \mathrm{wt} \%$ pulverized $\mathrm{PbF}_{2}$; further, $20 \mathrm{wt} \%$ acetylene black (AB) was mixed for $1 \mathrm{~h}$ in the planetary ball mill at $1100 \mathrm{rpm}$ to produce $\mathrm{PbF}_{2} / \mathrm{C}$. The $\mathrm{PbF}_{2}$ and $\mathrm{AB}$ were sealed in the planetary ball mill under a high purity argon atmosphere.

2.3. Characterization of the active material

For $\mathrm{PbF}_{2} / \mathrm{C}$, the crystal structure, particle configuration, and solubility in the electrolyte were investigated by X-ray diffraction (XRD), scanning electron microscopy (SEM), and atomic absorption spectrometry (AAS). The XRD measurements were performed with a Rigaku Smartlab. XRD patterns were recorded in the $2 \theta$ range from $20^{\circ}$ to $70^{\circ}$ using a Rigaku diffractometer with $\mathrm{Cu} \mathrm{K \alpha}$ radiation $(\lambda$ $=1.54 \AA$ ). The SEM measurements were performed on a HITACHI SU6600 instrument, and the energy of the incident electrons was $20 \mathrm{keV}$. The AAS measurements were performed using a polarized Zeeman atomic absorption spectrophotometer (Hitachi).

2.4. Characterization of electrolyte 
To evaluate the stability of the electrolyte during cycling, cyclic voltammetry (CV) was conducted using a three-electrode electrochemical cell (EC FRONTIER CO., Ltd. VB7) comprising a platinum foil working electrode, a platinum mesh counter electrode, and a silver rod immersed in acetonitrile containing $0.1 \mathrm{~mol} \mathrm{dm}^{-3}$ silver nitrate and $0.1 \mathrm{~mol} \mathrm{dm}^{-3}$ tetraethylammonium perchlorate as the reference electrode ( $0.587 \mathrm{~V}$ vs. standard hydrogen electrode) [33]. The CV of the prepared electrolyte was performed at room temperature using a multipotentiostat (Biologic VMP-300) over a -4.0 to $2.0 \mathrm{~V}$ (vs. ref.) potential range at a sweep rate of $0.1 \mathrm{mV} \mathrm{s}^{-1}$ during the three cycles. The assembly of electrochemical call and CV measurements were performed in a glove box filled with high purity argon.

\subsection{Electrochemical performance of $\mathrm{PbF}_{2} / \mathrm{C}$}

Firstly, the $\mathrm{PbF}_{2} / \mathrm{C}, \mathrm{AB}$, and polyvinylidene difluoride (75: 10: $15 \mathrm{wt} \%$ ) were mixed, and $\mathrm{N}-$ methyl-2-pyrrolidone (NMP) was added. The resulting slurry was coated on an Al current collector, and the NMP was evaporated at $110^{\circ} \mathrm{C}$. The charge and discharge capacities of the $\mathrm{PbF}_{2} / \mathrm{C}$ electrode were measured using a three-electrode electrochemical cell consisting of a $\mathrm{PbF}_{2} / \mathrm{C}$ electrode as the working electrode, a platinum mesh as the counter electrode, and a silver rod immersed in acetonitrile containing $0.1 \mathrm{~mol} \mathrm{dm}^{-3}$ silver nitrate and $0.1 \mathrm{~mol} \mathrm{dm}^{-3}$ tetraethylammonium perchlorate as the reference electrode. The charge and discharge measurements were performed using a multipotentiostat 
(Biologic VMP-300) within a potential range from -2.0 to $-0.6 \mathrm{~V}$ (vs. ref.) at $0.025 \mathrm{C}\left(\sim 20 \mu \mathrm{A} \mathrm{cm}^{-2}\right)$ and room temperature in an argon atmosphere. The specific capacity was obtained by dividing the capacity with the weight of the active material $\left(\mathrm{PbF}_{2}\right)$.

2.6. Crystal structure of $\mathrm{PbF}_{2} / \mathrm{C}$ in the pristine and during the charge-discharge cycle

The crystal structures of $\mathrm{PbF}_{2} / \mathrm{C}$ during the charge-discharge processes in the first and second cycles were evaluated using $\mathrm{XRD}$. After the $\mathrm{PbF}_{2} / \mathrm{C}$ electrodes were charged and discharged, they were washed with G4 followed by dimethyl carbonate to eliminate the residual electrolyte. The $\mathrm{XRD}$ patterns were recorded in the $2 \theta$ range from $25^{\circ}$ to $45^{\circ}$.

2.7. Dissolution amount of $\mathrm{Pb}$ in the electrolyte during the charge-discharge processes

The dissolution amount of $\mathrm{Pb}$ in the electrolyte in the first fully charged and discharged states was measured by AAS. After the $\mathrm{PbF}_{2} / \mathrm{C}$ electrode was charged and discharged, the electrochemical cell was disassembled, and the electrolyte was recovered from the cell. The concentration of $\mathrm{Pb}$ in the electrolyte was measured.

\section{Results and discussions}

\subsection{Characterization of $\mathrm{PbF}_{2} / \mathrm{C}$}


The XRD pattern of $\mathrm{PbF}_{2} / \mathrm{C}$ powder is illustrated in Fig. 1. All the diffraction peaks are assigned to the cubic phase with space group $F m 3 m$. The $\mathrm{SEM}$ images of $\mathrm{PbF}_{2}$ and $\mathrm{PbF}_{2} / \mathrm{C}$ powders are depicted in Fig. 2. The particle size of $\mathrm{PbF}_{2}$ (before mixing with $\mathrm{AB}$ ) is $0.5-2 \mu \mathrm{m}$ (Fig. 2(a)). After mixing with $\mathrm{AB}$, smaller particles of $\mathrm{AB}$ are observed on the $\mathrm{PbF}_{2}$ particle surfaces (Fig. 2(b)). This indicates that $\mathrm{AB}$ particles are adhered to the surface of the $\mathrm{PbF}_{2}$ particles after mixing.

3.2 Stability of electrolyte during the cycling

To evaluate the stability of the electrolyte during cycling, CV was performed. The CVs of the prepared electrolyte during the first, second, and third cycles are depicted in Fig. 3. There was a large reduction peak below $-2.2 \mathrm{~V}$ (vs. ref.) and a small oxidation peak between -0.3 and $0.5 \mathrm{~V}$ (vs. ref.) during the first cycle. The shapes of the CVs during the second and third cycles are similar to that during the first cycle. This indicates that the prepared electrolyte could be used repeatedly between -2.2 and $-0.3 \mathrm{~V}$ (vs. ref.).

\subsection{Electrochemical performance of $\mathrm{PbF}_{2} / \mathrm{C}$}

The charge and discharge curves of $\mathrm{PbF}_{2} / \mathrm{C}$ are depicted in Fig. 4. The charge and discharge capacities of $\mathrm{PbF}_{2} / \mathrm{C}$ during the first cycle were 175 and $240 \mathrm{mAh} \mathrm{g}^{-1}$, respectively. The discharge capacity exceeds the theoretical capacity $\left(219 \mathrm{mAh} \mathrm{g}^{-1}\right)$, which indicates that side reaction, such as 
decomposition of the electrolyte, occurs during discharging. The charge/discharge capacities during the second and third cycles are 128/183 and 88/124 $\mathrm{mAh} \mathrm{g}^{-1}$, respectively. Although the charge/discharge capacities gradually decreased during cycling, the charge/discharge reactions progressed during the second and third cycles. Furthermore, the shapes of the charge/discharge curves changed from the first to second cycle. The discharge onset potential changed from -1.05 (first cycle) to $-1.35 \mathrm{~V}$ (second cycle). Charging started at $-1.35 \mathrm{~V}$ during the first, second, and third cycles. In contrast, a plateau was observed at $-0.9 \mathrm{~V}$ during the first cycle; however, the charge potential gradually increased during the second and third cycles.

3.4. Confirmation of progress of the charge and discharge reactions

To confirm the progress of the charge and discharge reactions, the crystal structures of the $\mathrm{PbF}_{2}$ electrode in the charged and discharged states were confirmed using XRD. The XRD patterns of the $\mathrm{PbF}_{2} / \mathrm{C}$ electrode during charging and discharging in the first cycle are depicted in Fig. 5. In the pristine state, all the diffraction peaks are indexed to $\mathrm{PbF}_{2}$. The intensities of peaks assigned to $\mathrm{PbF}_{2}$ decreased, and new peaks appeared at $2 \theta=31.3^{\circ}$ and $36.3^{\circ}$ in the partially discharged state $(100 \mathrm{mAh}$ $\mathrm{g}^{-1}$ ). These peaks are assigned to $\mathrm{Pb}$ metal (cubic phase). As discharging progresses, the peaks assigned to $\mathrm{PbF}_{2}$ vanish and the intensities of peaks assigned to $\mathrm{Pb}$ increase. These results indicate that the discharge reaction $\left(\mathrm{PbF}_{2}+2 \mathrm{e}^{-} \rightarrow \mathrm{Pb}+2 \mathrm{~F}^{-}\right)$progressed. Conversely, the intensities of peaks assigned 
to $\mathrm{Pb}$ decrease and those assigned to $\mathrm{PbF}_{2}$ increase in the partially charged state $\left(100 \mathrm{mAh} \mathrm{g}^{-1}\right)$. As charging processes, the peaks assigned to $\mathrm{Pb}$ vanish and the intensities of peaks assigned to $\mathrm{PbF}_{2}$ increase, indicating that the charge reaction $\left(\mathrm{Pb}+2 \mathrm{~F}^{-} \rightarrow \mathrm{PbF}_{2}+2 \mathrm{e}^{-}\right)$progressed. The XRD results indicate that $\mathrm{PbF}_{2}$ and $\mathrm{Pb}$ are formed during charging and discharging, respectively.

The crystal structures of the $\mathrm{PbF}_{2} / \mathrm{C}$ electrode in the fully charged and discharged states during the second cycle are also evaluated using XRD, and the results are presented in Fig. 6. The peaks assigned to the $\mathrm{Pb}$ metal were observed in the fully discharged state. Further, the peaks in the fully charged states are indexed to $\mathrm{PbF}_{2}$. These results indicate that $\mathrm{Pb}$ was formed during discharging and that $\mathrm{PbF}_{2}$ was formed during charging in the second cycle. The $\mathrm{XRD}$ results indicate that the charge and discharge reactions progressed during the second cycle.

\subsection{Mechanism of capacity degradation during cycling}

The XRD results for both the first and second cycles (Figs. 5 and 6) indicate that the charge

and discharge reactions progressed completely during both the cycles. However, the charge and discharge capacities gradually decreased during cycling. Furthermore, the dissolution of active material was employed in the electrochemical reaction. This means that the active material could be dissolved in the electrolyte. Thus, we expected that the active material may be dissolved in the electrolyte and be lost from the electrode. Further, the dissolution amount of $\mathrm{Pb}$ in the electrolyte 
during charging and discharging was evaluated by AAS. The dissolution amount of $\mathrm{Pb}$ in the electrolyte in the fully charged and discharged states during the first cycle is presented in Table 1 . The dissolution amount of $\mathrm{Pb}$ considerably increased from the fully discharged (1\%) to the fully charged states (13\%). This indicates that $\mathrm{Pb}$ dissolved slightly during discharging. In contrast, the dissolution of $\mathrm{Pb}$ progressed during charging. It can therefore be concluded that the dissolution of $\mathrm{Pb}$ progress during charging according to following reaction:

$$
\mathrm{Pb} \rightarrow \mathrm{Pb}^{2+}+2 \mathrm{e}^{-}
$$

The progress of above reaction causes the loss of active material from the electrode. The content of active material in the electrode directly affected the capacity; therefore, we attributed the capacity degradation to the loss of active material from the electrode. The progress of $\mathrm{Pb}$ dissolution might be influenced by the electrolyte composition; therefore, the type and concentration of AA should be investigated to suppress the dissolution of $\mathrm{Pb}$. It will improve the cycling performance of FSB.

\section{Conclusion}

The electrochemical properties of $\mathrm{PbF}_{2} / \mathrm{C}$ for the $\mathrm{FSB}$ were investigated using the developed electrolyte. The electrochemical reactions of the $\mathrm{PbF}_{2} / \mathrm{C}$ electrode were observed during the chargedischarge cycling. Although the charge-discharge capacities gradually decreased during the cycling, the charge-discharge reactions were observed in the following cycles. To confirm the progress of the 
charge and discharge reactions, the crystal structures of the $\mathrm{PbF}_{2} / \mathrm{C}$ electrode during charging and discharging in both the first and second cycles were evaluated using XRD. The XRD results indicated the complete formation of $\mathrm{PbF}_{2}$ and $\mathrm{Pb}$ during charging and discharging, respectively, in both the first and second cycles. The AAS results indicated that the active material was partially lost after charging. Therefore, we attributed the capacity degradation to the loss of active material due to the dissolution of $\mathrm{Pb}$.

\section{Acknowledgements}

This work was supported by the Research and Development Initiative for Scientific Innovation of New Generation Batteries (RISING) and Research and Development Initiative for Scientific Innovation of New Generation Batteries 2 (RISING2) projects from the New Energy and Industrial Technology Development Organization (NEDO), Japan. The authors thank Ms. Kiyomi Ishizawa, Ms. Ryoko Masuda, and Ms. Hisayo Ikeda for their experimental support. 


\section{Reference}

[1] Y. Nishi, J. Power Sources 100 (2001) 101-106.

[2] Y. Wang, B. Liu, Q. Li, S. Cartmell, S. Ferrara, Z.D. Deng, J. Xiao, J. Power Sources 286 (2015) $330-345$.

[3] T. Minato, T. Abe, Prog. Surf. Sci. 92 (2017) 240-280.

[4] C. Delmas, J.J. Braconnier, C. Fouassier, P. Hagenmuller, Solid State Ion. 3-4 (1981) 165-169.

[5] D. Aurbach, Z. Lu, A. Schechter, Y. Gofer, H. Gizbar, R. Turgeman, Y. Cohen, M. Moshkovich, E. Levi, Nature 407 (2000) 724-727.

[6] A. Eftekhari, J. Power Sources 126 (2004) 221-228.

[7] K.M. Abraham, Z. Jiang, J. Electrochem. Soc. 143 (1996) 1-5.

[8] M. A. Reddy, M. Fichtner, J. Mater. Chem. 21 (2011) 17059-17062.

[9] C. Rongeat, M. A. Reddy, R. Witter, M. Fichtner, J. Phys. Chem. C 117 (2013) 4943-4950.

[10] A. Grenier, A.Porras-Gutierrez, H. Groult, K.A. Beyer, O.J. Borkiewicz, K.W. Chapman, D. Dambournet, J. Mater. Chem. A 5 (2017) 15700-15705.

[11] M.A. Nowroozi, K. Wissel, J. Rohrer, A.R. Munnangi, O. Clemens, Chem. Mater. 29 (2017) $3441-3453$.

[12] F. Gschwind, Z. Zhao-Karger, M. Fichtner, J. Mater. Chem. A 2 (2014) 1214-1218.

[13] F. Gschwind, J. Bastien, J. Mater. Chem. A 3 (2015) 5628-5634. 
[14] X. Zhao, Z. Zhao-Karger, D. Wang, M. Fichtner, Angew. Chem. Int. Ed. 52 (2013) 13621-13624.

[15] X. Zhao, Q. Li, Z. Zhao-Karger, P .Gao, K. Fink, X. Shen, M. Fichtner, Appl. Mater. Interfaces 6 (2014) 10997-11000.

[16] K. Okazaki, Y. Uchimoto, T. Abe, Z. Ogumi, ACS Energy Lett. 2 (2017) 1460-1464.

[17] H. Konishi, T. Minato, T. Abe, Z. Ogumi, J. Electrochem. Soc. 164 (2017) A3702-A3708.

[18] V.Y. Kavun, A.B. Slobodyuk, E.A. Tararako, E.Y. Mikhteeva, Y.K. Goncharuk, N.F. Uvarov, V.I. Sergienko, Inorganic Mater. 41 (2005) 1388-1396.

[19] N.I. Sorokin, B.P. Sobolev, Crystallography Reports 52 (2007) 842-863.

[20] V.Y. Kavun, A.B. Slobodyuk, S.V. Gnedenkov, S.L. Sinebryukhov, V.K. Goncharuk, N.F. Uvarov, V.I. Sergienko, J. Struct. Chem. 48 (2007) 840-847.

[21] V.Y. Kavun, A.B. Slobodyuk, E.A. Tararako, V.K. Goncharuk, N.F. Uvarov, V.I. Sergienko, Inorganic Materials 43 (2007) 301-309.

[22] H. Li, P. Balaya, J. Maier, J. Electrochem. Soc. 151 (2004) A1878-A1885.

[23] N. Yabuuchi, M. Sugano, Y. Yamakawa, I. Nakai, K. Sakamoto, H. Muramatsu, S. Komaba, J Mater. Chem. 21 (2011) 10035-10041.

[24] M. Sina. K.W. Nam, D. Su, N. Pereira, X.Q. Yang, G.G. Amatucci, F. Cosandey, J. Mater. Chem. 1 (2013) 11629-11640.

[25] M.A. Reddy, B. Breitung, C. Wall, S. Trivedi, V. Sai, K. Chakravadhanula, M. Helen, M. Fichtner, 
Energy Technol. 4 (2016) 201-211.

[26] M. Bervas, F. Badway, L.C. Klein, G.G. Amatucci, Electrochem Solid-State Lett. 8 (2005) A179A183.

[27] M. Bervas, A.N. Mansour, W.S. Yoon, J.F. Al-Sharab, F. Badway, F. Cosandey, L.C. Klein, G.G. Amatucci, J. Electrochem. Soc. 153 (2006) A799-A808.

[28] A.J. Gmitter, F. Badway, S. Rangan, R.A. Bartynski, A. Halajko, N. Pereira, G.G. Amatucci, J. Mater. Chem. 20 (2010) 4149-4161.

[29] B. Hu, X. Wang, H. Shu, X. Yang, L. Liu, Y. Song, Q. Wei, H. Hu, H. Wu, L. Jiang, X. Liu, Electrochim. Acta 102 (2013) 8-18.

[30] H. Konishi, T. Minato, T. Abe, Z. Ogumi, Chemistry Select 2 (2017) 3504-3510.

[31] H. Konishi, T. Minato, T. Abe, Z. Ogumi, Chemistry Select 2 (2017) 6399-6406.

[32] H. Konishi, T. Minato, T. Abe, Z. Ogumi J. Electroanal. Chem. 806 (2017) 82-87.

[33] V.V. Pavlishchuk, A.W. Addison, Inorg. Chim. Acta 298 (2000) 97-102. 
Journal of Electroanalytical Chemistry, 826, 60-64 (2018).

\section{Table}

Table 1 Dissolution amount of $\mathrm{Pb}$ in the electrolyte in the fully charged and discharged states during the first cycle.

\begin{tabular}{cc}
\hline State & $\begin{array}{c}\text { Dissolution amount of } \mathrm{Pb} \\
(\%)\end{array}$ \\
\hline Completely discharged & 1 \\
Completely charged & 13 \\
\hline
\end{tabular}


Journal of Electroanalytical Chemistry, 826, 60-64 (2018).

\section{Figure}

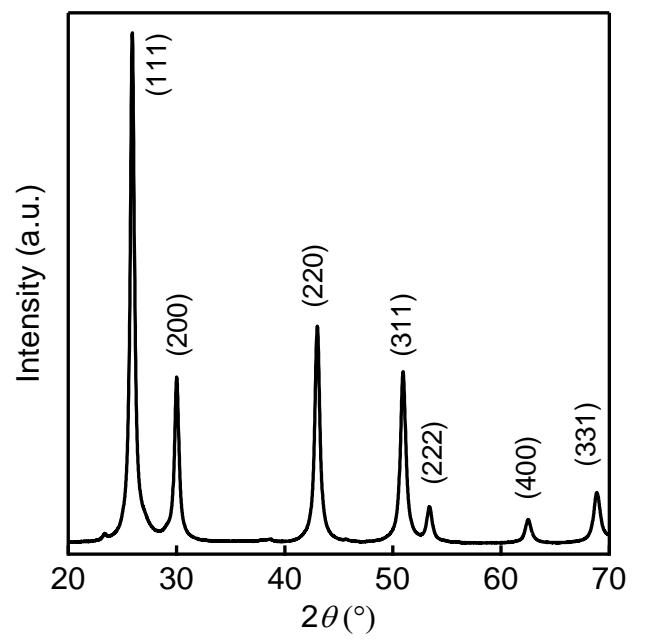

Figure $1 \mathrm{XRD}$ patterns of the $\mathrm{PbF}_{2} / \mathrm{C}$ powder. 
Journal of Electroanalytical Chemistry, 826, 60-64 (2018).

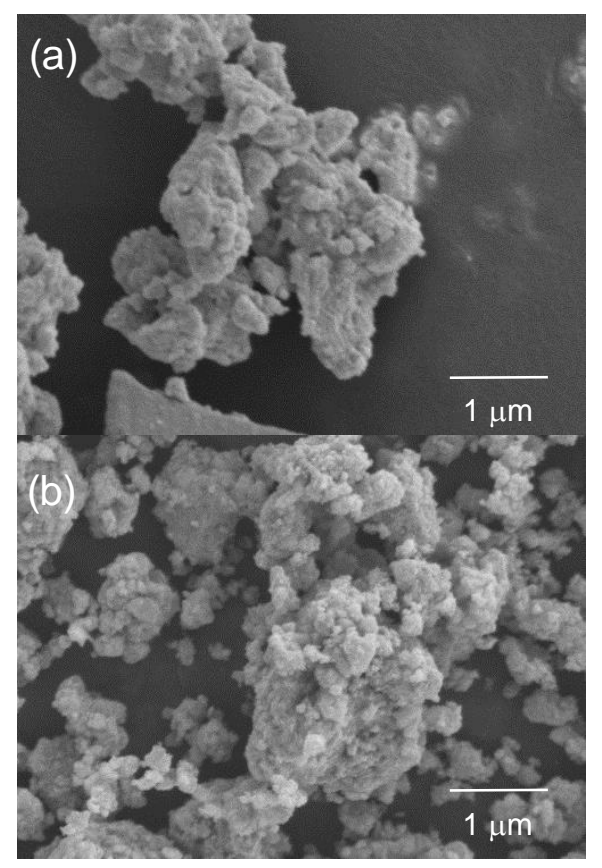

Figure $2 \mathrm{SEM}$ images of the (a) $\mathrm{PbF}_{2}$ and (b) $\mathrm{PbF}_{2} / \mathrm{C}$ powders. 


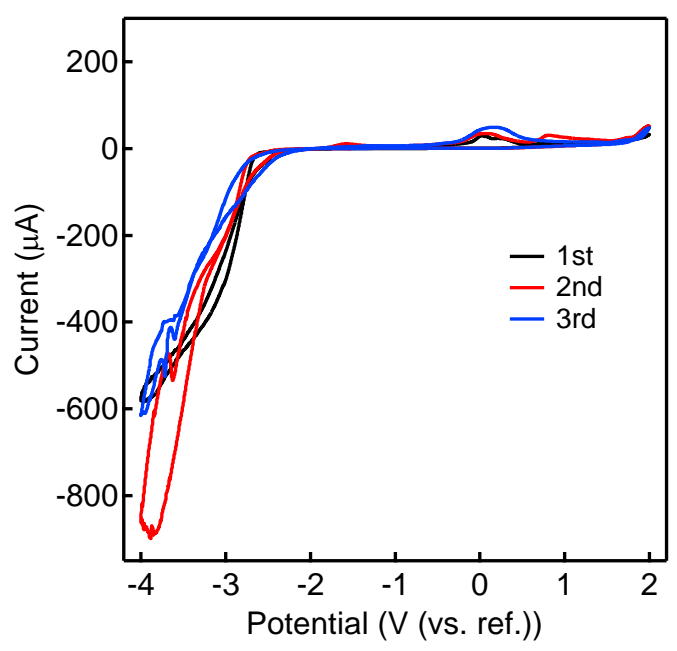

Figure 3 Cyclic voltammograms of the prepared electrolytes over the -4.0 to $2.0 \mathrm{~V}$ (vs. ref.) potential range during the first (black), second (red), and third (blue) cycles [The data were reproduced using the data of ref.[17]]. 


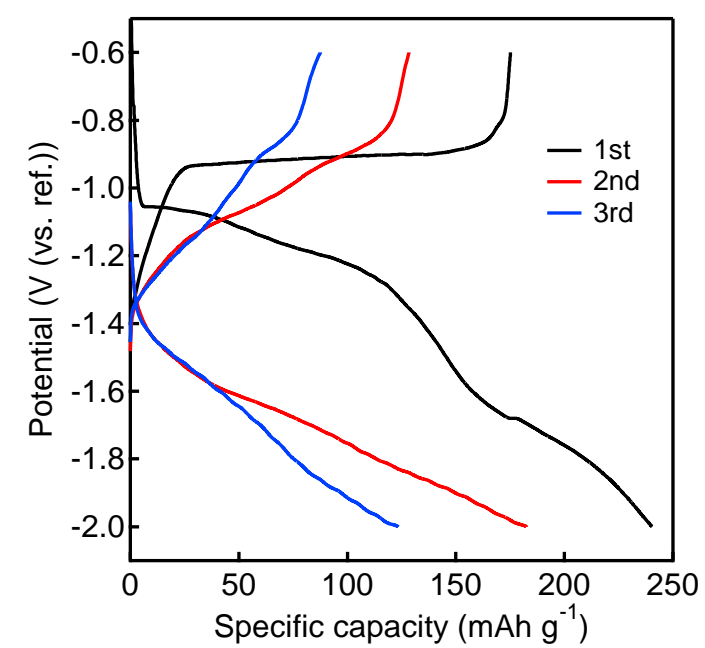

Figure 4 Charge and discharge curves of $\mathrm{PbF}_{2} / \mathrm{C}$ at $0.025 \mathrm{C}$ during the first (black), second (red), and third cycles within the potential range from -2.0 to $-0.6 \mathrm{~V}$ (vs. ref.). 


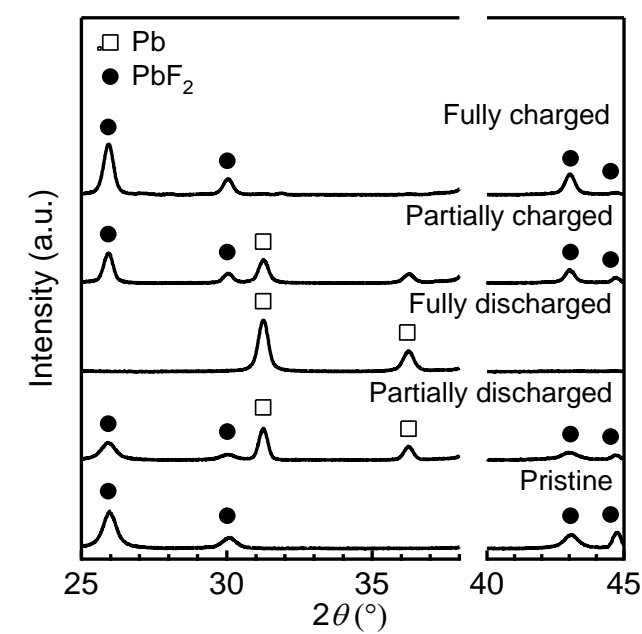

Figure $5 \mathrm{XRD}$ patterns of $\mathrm{PbF}_{2} / \mathrm{C}$ in the pristine, partially discharged $\left(100 \mathrm{mAh} \mathrm{g}^{-1}\right)$, fully discharged, partially charged (100 mAh g-1), and fully charged states during the first cycle. 
Journal of Electroanalytical Chemistry, 826, 60-64 (2018).

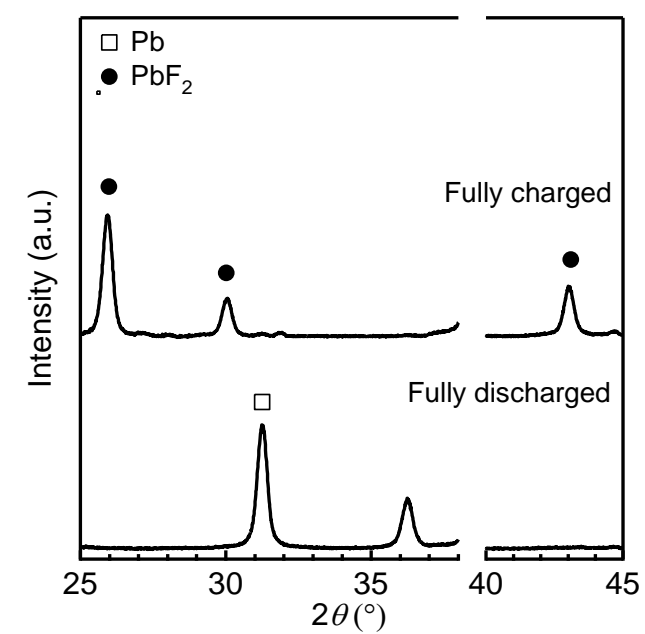

Figure $6 \mathrm{XRD}$ patterns of $\mathrm{PbF}_{2} / \mathrm{C}$ in the fully charged and discharged states during the second cycle. 